\title{
Professional Self-Efficacy Scale for Information and Computer Technology Teachers: Validity and Reliability Study
}

\author{
Koksal Banoglu ${ }^{1}$, Ruben Vanderlinde ${ }^{2}$ and Rauf Yildiz $^{3}$ \\ ${ }^{1}$ Marmara University and Ghent University, Department of Educational Studies, \\ Istanbul, Turkey \\ ${ }^{2}$ Ghent University, Department of Educational Studies, Ghent, Belgium \\ ${ }^{3}$ University of Canakkale 18 Mart, Education Faculty, Canakkale, Turkey \\ E-mail:1<koksal_banoglu@hotmail.com>, ${ }^{2}<$ ruben.vanderlinde@ugent.be $>$, \\ $3<$ raufyildiz17@gmail.com>
}

KEYWORDS Teacher Self-efficacy. ICT Competency. ICT Framework. Technology Leadership. Scale Development

\begin{abstract}
This study aims at developing a valid and reliable scale to measure information and communication technology (ICT) teachers' self-efficacy related to the Turkish national framework of ICT competencies. For statistical procedures, data were respectively analyzed with exploratory factor analysis (EFA) and confirmatory factor analysis (CFA). Furthermore, test-retest procedure was carried out to confirm the time invariance of the scale. EFA results revealed that the scale's seven-factor structure accounts for 65.90 percent of total variance. CFA results produced an acceptable statistical support for model-data fit between the observed item scores and the seven-dimension scale structure $\left(\mathrm{X}^{2} / \mathrm{df}=1.98, \mathrm{RMSEA}=.073, \mathrm{CFI}=.86\right)$. The standardized regression weights between the latent and observed variables ranged from .57 to .89 and Cronbach's alpha coefficient of the scale subdimensions ranged from .80 to .88 . Besides, the item-scale correlations varied between values of .53 and .79. As a result, the developed scale is a likert questionnaire and composed of 33 five-point items with seven sub-dimensions.
\end{abstract}

\section{INTRODUCTION}

Recent years have witnessed rapid and extensive advances in education technologies. Aligned with drastic changes in technology-assisted instructional methods, not surprisingly, teachers are expected to keep pace with the advancements and latest developments in the instructional technologies. Not only school managers urge teachers to be tech-savvy with up-todate technology trainings but also social expectations give rise to observable difference in teacher behaviors towards the technology (Papa 2010).

On the other hand, it should be kept in mind that administrative incentives and social expectations are not unique parameters to account for teachers' technology competencies. In this sense, it is evident that ICT coordinator teachers (ICT teachers) play a major role in affecting other teachers' perception of technology (Lesisko 2005). Forasmuch as they hold the key position to increase the use of educational technology by teachers, no doubt they ought to hold a positive perception about it. ICT teachers become then change agents, and as such, can facilitate learning and instruction with the support of ICT (Strudler 1995). And, more important, ICT coordinators should have a high professional self- efficacy, since learning how to incorporate technology into instructional process requires selfconfidence and self-efficacy (Brinkerhoff 2006).

Bandura (1986) defined self-efficacy as individual judgments about one's own capabilities to organize himself/herself and get into action in alignment with desired goals. Hence, computer self-efficacy can be defined as one's judgement on his/her own potential to use computer (Compeau and Higgins 1995). Teachers with higher levels of self-efficacy about ICT or computers, use computers more and experience less computer-related anxiety (Sam et al. 2005). Self-efficacy plays such a major role in shaping learning environment that some scholars explicitly ascribe teacher beliefs about the constructivist teaching methods to their ICT self-efficacy perceptions (Teo et al. 2008). Lai and Pratt (2004) claimed that ICT teachers have important influence on faculty's perception of education technology. Those studies also ignited further discussion on ICT teachers and their self-efficacy beliefs.

Brinkerhoff (2006) asserted four potential obstacles that enable to prevent technology integration into education in some way, such as technological resource availability, institutional and administrative support for technology improvement, teachers' professional training and 
experience, teacher attitude towards technology. Prain and Hand (2003) claimed that teachers might have an attitude against technology tools with which they have little experience or when they fall behind their students' technology literacy level. Indeed, teacher knowledge of educational technology is increasing gradually and, what is more, once teachers are acquainted with how the proper use of ICT can make a practical contribution to learning environment and their professional development, it results in more effective technology use in classrooms and vice versa (Dagiene 2003; Settlage et al. 2004).

ICT teachers' professional self-efficacy is a considerable challenge to to focus on because those teachers who are nominated as both formal and informal technology leaders, are also responsible for encouraging their colleagues to make use of ICT tools. Despite the multiple role description of ICT teachers (for example, Devolder et al. 2010), varied widely from country to country without consensus about their tasks (Frazier and Bailey 2004), their major role is often restricted to incorporate ICT tools into curriculum somehow. Ross et al.'s survey (2001) found out ICT teachers' competency explains student achievement in rates ranging from 7 percent to 9 percent. According to Lesisko (2005), technology coordinators' features, which cannot be limited within the teaching process, play a vital role for school principals in fulfilling their technology leadership responsibilities. Also Banoglu (2011) laid stress on technology coordinator teachers' significant role on the technology leadership function of school principals. In addition to public and private coordinating activities they perform, ICT teachers contribute to school improvement as an instructional designer and technology/media specialist. Accordingly, depending on a school's strategic objectives, region and facilities, ICT teachers also take on many tasks such as network specialist, expert of maintenance and repair of electronic tools and technology etc. (Lesisko 2005). Devolder et al. (2010) cluster these tasks in four roles: the ICT teacher as a technician, a planner, a budgeteer, and an educationalist. To conclude, ICT teacher's professional competency issue maintains its place as a popular subject for researchers.

There are a lot of competency frameworks for ICT teachers, constructed on the basis of different standards developed by various institutions or governments. All these frameworks have in common that they act as blueprints for the acquisition of the so-called $21^{\text {st }}$ Century Skills (Aesaert et al. 2013). For instance in the USA, teachers are anticipated to meet different competency frameworks such as "Code of Ethics for Educational Leaders" of American Association of School Administrator (AASA), "The Educational Leadership Policy Standards” of the Interstate School Leaders Licensure Consortium (ISSLC) or the "National Educational Technology Standards" (NETS) of the International Society for Technology in Education (ISTE) (Papa 2010). According to NETS-T standards - which are developed especially for teachers - ICT teachers are anticipated to catch the following five standards whose levels are identified as starting, developed, expert, and converter. They are briefly described as follows (ISTE 2008):

1. Being able to help and inspire students in learning and creativity;

2. Being able to create and develop learning experiences and evaluating tools of the digital age;

3. Being able to create a working model for studying and learning processes of the digital age;

4. Being able to create a working model for developing digital citizenship and its responsibilities; and

5. Being concerned with professional development and leadership.

Unlike these standards are developed by non-governmental organisations, the technology competency frameworks are determined by the Ministries of education in many European countries so that pre-service teachers gain technology assisted teaching skills through either elective or core courses offered by teacher training institutions (Eurydice 2004). In Australia, for instance, there is a broad range of criteria and they differ from each other in every region. To give an example from Queensland district of Australia, four competency standards for teachers are identified as computer skills, classroom practice and lesson planning, curriculum development and student-centered teaching, respectively. On the other hand, the competency areas in the Northern region are identified as: having vision, values and ethical approach to technology, integration of ICT tools and applications into classroom practice (Queensland Department of Education 1999).

In Turkey, competency framework for ICT teachers has been constructed by TMONE (Turk- 
ish Ministry of National Education). Being an ICT teacher is considered as "being the leader of change" in the teaching process. This expression literally depicted TMONE's modern technology vision for ICT teachers (TMONE 1993). In this manner, "general teacher competency framework" was declared by TMONE in relation with six main competencies, 31 sub-competencies and 233 performance indicators. In retrospect, TMONE's official meetings for research studies on teachers' efficiency criterions date back to 2004. In due course, scholarly meetings and workshops brought about 14 special efficiency areas for distinct lessons. Of those areas, "professional competency framework for ICT teachers" was launched on 25 July 2008.

According to the results of a qualitative study conducted by Keskinkilic (2010) in Turkey, based on the opinions of school principals, ICT teachers are efficient enough in the following sub-competencies: course planning; proper usage of the ICT terms; creating technologysupported teaching environments in the face of students' learning needs; benefiting from the technology to access, use and evaluate information; taking the necessary measures for health and safety while using computer; obeying to the relevant ethical, legal and moral rules; and active use of internet and other networks. Nonetheless, Keskinkilic (2010) indicated that they are not efficient in some sub-competencies such as establishing an operating system and self-improvement for hardware issues at school.

In this case, it seems to be important to identify the competency levels in the light of "professional competency framework" for both onduty ICT teachers and pre-service teachers. For this purpose, it is needed to develop a reliable and valid self-efficacy measurement instrument for ICT teachers.

In other words, the purposes of this study can be summarized as follows: 1 ) to identify draft items owing to official framework that laid down by TMONE; 2) to develop a self-efficacy scale regarding relevant competencies; and 3) to confirm the reliability and validity of this scale in terms of psychometric properties.

\section{METHODOLOGY}

\section{Research Population}

The population of this study was made up of 190 ICT pre-service teachers who study at
Computer and Information Technologies Education (CITE) departments of three state universities in Turkey. Apart from the main research population, 67 pre-service teachers administrated test-retest reliability analyses performed at 2 weeks intervals. Out of the 190 ICT pre-service teachers 60 percent (114) were male and 40 percent (76) were female students.

\section{Sample Size}

As a general rule of thumb regarding sample size, there should be at least 5 participants per item for reliability and validity analyses procedures (Gorsuch 1983; Streiner 1994; Tavsancil 2002). Sample size of the present study (that is, 190 participants) may be regarded acceptable according to 5:1 participants per variable (that is, 33-items) rule of thumb.

Additionally, Ullman (2001) indicated that the general guidelines for sample size might be misleading without taking into consideration the analysis results of datasets. For instance, Worthington and Whitetaker (2006) suggested that sample sizes of 150-200 is likely to be adequate with datasets including communalities of .50 or greater. For this study, it is estimated that all communalities of items produce greater values than .50 with values ranging from .50 to.84. In that manner, this study's sample size may be considered large enough to provide adequate evidence for reliability and validity analyses.

\section{Data Collection Tool}

Initially, a 53-items draft was constructed in accordance with the official national ICT framework of TMONE. Next, as for experts' opinions, a validation panel composed of four scholars in the field of CITE reviewed the 53-item first draft scale to evaluate the face validity along with the content validity. Appropriate revisions and modifications were made as deemed necessary from the scholars' evaluation. Table 1 shows some expert opinions and revisions. Based upon the experts' suggestions, some items pertaining to the national teacher competency framework were subject to being ideological. Because of the relevant critiques and being openness to further discussions (Vossler 2006; Ministère de l' Education 2011), these items were initially excluded from the instrument. 
Table 1: Sample expert opinions

\begin{tabular}{|c|c|c|}
\hline Items before review & Expert-proposal for items & Revised items \\
\hline $\begin{array}{l}\text { I can develop instructional } \\
\text { materials by using MS Office } \\
\text { programs. (Draft Item) }\end{array}$ & $\begin{array}{l}\text { “Using only office programs are not } \\
\text { adequate and satisfactory for } \\
\text { assessing ICT teachers' skills } \\
\text { for developing instructional } \\
\text { material. So item should be improved } \\
\text { by stressing software types.” } \\
\text { (Reviewer 1)” }\end{array}$ & $\begin{array}{l}\text { In addition to MS Office programs, this } \\
\text { item is to be revised in a way that it } \\
\text { covers other similar software } \\
\text { applications.” (Reviewer 3) } \\
\text { I can develop instructional materials } \\
\text { by using word processor software } \\
\text { applications (item-24). I } \\
\text { I can develop instructional materials } \\
\text { by using spreadsheet software } \\
\text { applications (item-25). } \\
\text { I can develop instructional materials } \\
\text { by using presentation software } \\
\text { applications (item-26) } \\
\text { I can develop instructional materials } \\
\text { by using database software } \\
\text { applications (item-27) } \\
\text { I can develop instructional materials } \\
\text { by using desktop publishing software } \\
\text { applications (item-28) }\end{array}$ \\
\hline $\begin{array}{l}\text { I can stimulate students to } \\
\text { make proper slide shows to } \\
\text { be demonstrated in national } \\
\text { celebrations at school. } \\
\text { (Draft Item) } \\
\text { I can integrate Ataturkcu } \\
\text { "(Kemalist)" values into } \\
\text { ICT curriculum (Draft Item) }\end{array}$ & $\begin{array}{l}\text { “Although the offical competency } \\
\text { framework contains some abstract } \\
\text { national and political content, } \\
\text { obviously there is no relationship } \\
\text { between national-ideological } \\
\text { topics and ICT teachers” } \\
\text { professional competencies. } \\
\text { So these must be extracted from } \\
\text { the scale.” (Reviewer 4) }\end{array}$ & $\begin{array}{l}\text { Both items were extracted from the } \\
\text { scale. }\end{array}$ \\
\hline $\begin{array}{l}\text { I can prepare web-based } \\
\text { instructional materials. } \\
\text { (Draft Item) }\end{array}$ & $\begin{array}{l}\text { "The item should emphasize multi- } \\
\text { media content of web-based materials } \\
\text { and yet it defines no qualification } \\
\text { about web-based materials." } \\
\text { (Reviwer 2) }\end{array}$ & $\begin{array}{l}\text { I can prepare web-based instructional } \\
\text { materials in line with the principles } \\
\text { of multi-media (Item-9). }\end{array}$ \\
\hline
\end{tabular}

\section{Data Analysis}

Dataset was analyzed by respectively exploratory factor analysis (EFA) and confirmatory factor analysis (CFA). During EFA procedures, the technique of principal component analysis was employed to reduce prospective dimensions. From the orthogonal rotation techniques, whose common goal is to maximize the variance of factor loadings, the varimax method was employed to eliminate the irrelevant variables, which often results in low correlations among the factors (Ullman 2001; Hair et al. 2010). Measurement model that will be examined through CFA was designed in accordance with the factor structure identified in the EFA procedure. In order to evaluate the theoretical model-observed data fit, $\mathrm{X}^{2} /$ df (chi-square/degree of freedom), Comparative Fit Index (CFI) and Root Mean Square Error of Approximation (RMSEA) indices were preferred because those are the most frequently reported ones and what is more, CFI and X2/df ratios are relatively immune to possible misleading effects stemming from sample size (Ullman, 2007). In addition to fit indices, convergent and discriminant validity of the measurement model was examined estimating composite reliability (CR), average variance extracted (AVE), maximum shared squared variance (MSV) and average shared squared variance (ASV) values.

\section{RESULTS}

Prior to factor analysis, it is recommended to calculate Kaiser-Meyer-Olkin (KMO) measure of sampling adequacy, in addition to checking significance of Bartlett's test so as to understand whether covariance matrix is suitable for factor analysis. For this study, KMO was found to be .876 and Bartlett's sphericity test was significant at the 99 percent confidence interval, which confirmed the appropriateness of the data for EFA. 
Afterwards, EFA was carried out with the extraction method of principal component analysis. Table 2 shows the estimated factor loadings of items with their explanations.

Of the 45 items, 11 ones were eliminated from EFA due to either poor factor loading or excessively cross-loadings. Eventually, EFA yielded a clean seven-factor solution with the minimum eigenvalue of 1 . Among the remained items, the lowest factor loading was calculated to be .596, whereas the highest one was .842. The sevenfactor construct, when all the percentages are summed up, accounted for 65.90 percent of the overall variance as seen at Table 2.

Since the researchers' measurement survey relied on self-reported questionnaire, it was important to ascertain to which extent the common method bias (CMB) exists. Correspondingly, Harman's single factor test was conducted to statistically explore the prospective effect size of CMB. In brief, Harman's single factor test is an EFA of all variables to determine how much variance might be ascribed to a forced singlefactor. In case this common factor explained more than 50 percent of the total variance there could be an issue with CMB (Podsakoff et al. 2003). The test results showed that, when all 34 items were loaded into one general factor, the relevant single-factor represented only 29.60 percent of the total variance. Therefore it was evidenced that the developed measurement model was immune to common method bias.

For a next step, data were investigated by confirmative follow-up study on that whether the factor structure identified in EFA is consistent with the collected data or not. To begin with, the measurement model to be examined by CFA was initially formulated based on the seven-factor solution extracted in EFA. Each factor was depicted as an unobserved (latent) variable and hence seven-factor model with 34 items get into analysis. After removing Item-19 from the model due to its high standardized residuals of 3.212, the second model (33-item) produced acceptable goodness-of-fit scores. Besides, modification indices for covariances suggested a linkage between the error terms of Item-15 and Item-14, Item16 and Item-17, Item-39 and Item 40. By this means, the last modified model revealed slightly better goodness-of-fit scores $\left(\mathrm{x}^{2} / \mathrm{df}=1.98\right.$; $\mathrm{RM}$ $\mathrm{SEA}=.073, \mathrm{CFI}=.86$ ).

The literature review undertaken to evaluate the evidence for the model-data fit elicited that in case the ratio of $x^{2}$ to degree of freedom is less than 5, it displays an acceptable model-data fit (Gillaspy 1996; Schumacker and Lomax 2004). Provided that the ratio between values of 2 and 3 , it can be interpreted as an indicator for an acceptable model-data fit (Ullman 2001). CFI index yields a fit index that lies just in the 0 to 1 range. CFI value of 0.90 and above is considered sufficient for an acceptable fit. RMSEA value of 0.80 and less is taken as evidence of acceptable fit (Sumer 2000; Albright and Park 2009). Based upon these criteria, the measurement model produced $\mathrm{x}^{2} / \mathrm{df}$ ratio of 1.99 indicating a perfect model-data fit $(p<.001)$. Additionally, the RMSEA value of .073 is less than threshold value of .080. That is, the current model has a reasonable fit with the collected data. However, CFI value of .86, a little less than .90 , revealed the our model slightly falls short of the conventional cut-off point, but just a little below that. Insofar as such a small amount of deviation (that is, .04) from the threshold came into question, it was not considered as a significant violation of model-data agreement. Therefore, on the whole, the construct validity of the seven-factor measurement model with 33 items appears to be reasonably adequate. Figure 1 illustrates the measurement model and the relevant standardized estimates for further examination.

Factor loadings (standardized regression weights) across the seven factors ranged from .58 to .90. Examination of the factor loadings revealed that all 33 items have significant loadings on the construct and none of them exceeds the cut-off value of $\geq 50$, which is a recommended point especially for measurement models including newly developed items (Hulland 1999). Internal consistency reliability of the seven factors ranged from .80 to .88 Cronbach alpha values. Another point to check is that the estimated correlations between factors did not exceed the absolute point of .90 (Kline 2011). The convergent and discriminant validity of the model were examined by calculating CR, AVE, MSV and ASV values by using the regression weights and correlation coefficients presented on Figure 1 . These values are presented in Table 3 .

The above pattern of results revealed that the mentioned values were evidence of the measurement model's validity in question. That is, CR exceeds both AVE and value of .7 for each case. Also it is seen that AVE exceeds MSV and ASV. Additionally, AVE value is greater than the 
Table 2: Factor loadings and explained variances

\begin{tabular}{|c|c|c|c|c|c|c|c|}
\hline \multirow[t]{2}{*}{ Items } & \multicolumn{5}{|c|}{ Factor loads after conversion value } & \multirow{2}{*}{$\begin{array}{l}\text { Eigen } \\
\text { vari- } \\
\text { ance }\end{array}$} & \multirow{2}{*}{$\begin{array}{l}\text { Expla- } \\
\text { ined }\end{array}$} \\
\hline & $F 1$ & $F 2$ & F3 & $F 4$ & F5 F6 F7 & & \\
\hline $\begin{array}{l}\text { I.15) I can solve confronted software/ } \\
\text { equipment problems. }\end{array}$ & .828 & 3.070 & .019 & .067 & $7.057 .012-.024$ & 4.589 & $13.50 \%$ \\
\hline $\begin{array}{l}\text { I.14) I can detect software/equipment problems } \\
\text { that can be faced. }\end{array}$ & .824 & 4.115 & .161 & .035 & $5.087 .015-.060$ & & \\
\hline $\begin{array}{l}\text { I.13) I can use different versions of available } \\
\text { operating systems. }\end{array}$ & .709 & .136 & -.072 & .172 & $2.054-.096 .070$ & & \\
\hline $\begin{array}{l}\text { I.16) I can carry out operations using file } \\
\text { extensions programs. }\end{array}$ & .700 & .101 & -.004 & .082 & 2.096 .171 .146 & & \\
\hline $\begin{array}{l}\text { I.18) I can work computer and environment } \\
\text { units on a network. }\end{array}$ & .683 & 3.060 & .191 & .311 & $1-.043 .268-.019$ & & \\
\hline $\begin{array}{l}\text { I.19) I can use programs required for network } \\
\text { administrations. }\end{array}$ & .631 & .101 & .061 & .278 & -.007 .316 .063 & & \\
\hline $\begin{array}{l}\text { I.12) I can set up a computer system } \\
\text { appropriate to its purpose. }\end{array}$ & .614 & .059 & .130 & -.024 & .439 .064 .252 & & \\
\hline $\begin{array}{l}\text { I.17) I can prepare activities for learners' } \\
\text { sharing files. }\end{array}$ & .609 & .234 & .127 & .155 & . 156.213 .147 & & \\
\hline $\begin{array}{l}\text { I.36) I can rearrange ICT learning environment } \\
\text { in direction of evaluation results. }\end{array}$ & .055 & .736 & .255 & .064 & . 132.145 .027 & 4.487 & $13.19 \%$ \\
\hline $\begin{array}{l}\text { I.34) I can give feedback to learners about } \\
\text { ICT objectives, methods, results of } \\
\text { measurement and evaluation. }\end{array}$ & .188 & .731 & .048 & .024 & 208. & & \\
\hline $\begin{array}{l}\text { I.31) I can determine the learner's ICT level } \\
\text { through measurement and evaluation process. }\end{array}$ & .032 & .715 & .066 & .010 & .065-.140.223 & & \\
\hline $\begin{array}{l}\text { I.35) I can test the validity and reliability of } \\
\text { measurement instrument to evaluate learner } \\
\text { products. }\end{array}$ & .019 & .691 & .202 & .072 & . 082.116 .097 & & \\
\hline $\begin{array}{l}\text { I.37) I can record learner's measurement } \\
\text { and evaluation results in computer } \\
\text { environment. }\end{array}$ & .199 & .677 & .231 & .214 & .067.153-.167. & & \\
\hline $\begin{array}{l}\text { I.38) I can give feedback to learners concerning } \\
\text { their academic achievement via internet. }\end{array}$ & .167 & .642 & .031 & .321 & .022.067-.073 & & \\
\hline $\begin{array}{l}\text { I.32) I can use the evaluation tools peculiar } \\
\text { to ICT. }\end{array}$ & .155 & .626 & .343 & .017 & $.006-.046 .290$ & & \\
\hline $\begin{array}{l}\text { I.33) I can evaluate both learner's ICT } \\
\text { learning processes and products appropriate } \\
\text { to curriculum. }\end{array}$ & .126 & .596 & .270 & .069 & $.132-.119 .263$ & & \\
\hline $\begin{array}{l}\text { I.02) I can plan the instructional process } \\
\text { taking learners' level of progress into } \\
\text { consideration. }\end{array}$ & .080 & .159 & .822 & .175 & 180.095. & 3.395 & $9.99 \%$ \\
\hline $\begin{array}{l}\text { I.3) I can plan the instructional process } \\
\text { taking learners' learning styles into } \\
\text { consideration. }\end{array}$ & .019 & .138 & .815 & .150 & .087.067-.054 & & \\
\hline $\begin{array}{l}\text { I.5) I can plan the instructional process } \\
\text { in a way that the learner can reflect it on } \\
\text { his daily life. }\end{array}$ & .102 & .278 & .694 & .069 & -.027 .084 .000 & & \\
\hline $\begin{array}{l}\text { I.1) I can plan the instructional process } \\
\text { taking learners' needs into consideration }\end{array}$ & .158 & .233 & .683 & -.025 & . 198.013 .072 & & \\
\hline $\begin{array}{l}\text { I.4) I can plan the instructional process } \\
\text { through linking it with different fields } \\
\text { unlike ICT. }\end{array}$ & -.008 & .150 & .621 & -.055 & .114 .135 .204 & & \\
\hline $\begin{array}{l}\text { I.40) I can inform learners about the ethical } \\
\text { dimension of technology use. }\end{array}$ & .131 & .104 & .261 & .806 & $.044-.007 .098$ & 3.035 & $8.92 \%$ \\
\hline $\begin{array}{l}\text { I.42) I can recognize the threats from the } \\
\text { internet. }\end{array}$ & .252 & .096 & -.029 & .772 & 142.093. 048. & & \\
\hline $\begin{array}{l}\text { I.43) I can take measure against threats } \\
\text { from the internet. }\end{array}$ & .279 & .029 & -.027 & .760 & 132. 163. & & \\
\hline $\begin{array}{l}\text { I.39) I can raise learners' awareness of health } \\
\text { problems originating from technology. }\end{array}$ & .073 & .250 & .093 & .755 & .083 .064 .008 & 2.776 & $8.17 \%$ \\
\hline
\end{tabular}


Table 2: Contd...

\begin{tabular}{|c|c|c|c|c|c|c|c|}
\hline \multirow[t]{2}{*}{ Items } & \multicolumn{5}{|c|}{ Factor loads after conversion value } & \multirow{2}{*}{$\begin{array}{l}\text { Eigen } \\
\text { vari- } \\
\text { ance }\end{array}$} & \multirow{2}{*}{$\begin{array}{l}\text { Expla- } \\
\text { ined }\end{array}$} \\
\hline & F1 & $F 2$ & F3 & F4 & F5 $\quad F 6 \quad F 7$ & & \\
\hline $\begin{array}{l}\text { I.27) I can develop instructional materials } \\
\text { by using database software applications }\end{array}$ & -.028 & .117 & .218 & .152 & .762 .033 .000 & & \\
\hline $\begin{array}{l}\text { I.28) I can develop instructional materials } \\
\text { by using desktop publishing software } \\
\text { applications }\end{array}$ & .104 & .098 & .189 & .098 & .730 .148 .142 & & \\
\hline $\begin{array}{l}\text { I.29). I can enrich learning activities using } \\
\text { the animation programs. }\end{array}$ & .126 & .266 & .076 & .180 & $.711 .222-.015$ & & \\
\hline $\begin{array}{l}\text { I.30) I can design web-supported teaching } \\
\text { materials using the codes particular to a } \\
\text { programming language. }\end{array}$ & .257 & .020 & .006 & .002 & .707 .285 .129 & 2.415 & $7.10 \%$ \\
\hline $\begin{array}{l}\text { I.8) I can develop web-based distance } \\
\text { education materials. }\end{array}$ & .113 & .024 & .056 & .145 & .234 .842 .114 & & \\
\hline $\begin{array}{l}\text { I.9) I can prepare web-based instructional } \\
\text { materials in line with the principles of } \\
\text { multi-media. }\end{array}$ & .151 & .225 & .153 & .005 & .219 .799 .105 & & \\
\hline $\begin{array}{l}\text { I.7) I can develop educational software } \\
\text { appropriate to the teaching objectives. }\end{array}$ & .277 & -.065 & .199 & .201 & .204 .636 .018 & & \\
\hline $\begin{array}{l}\text { I.11) I can prepare learning activities with } \\
\text { the purpose of making learners use ICT } \\
\text { terms properly. }\end{array}$ & .094 & .387 & .140 & .161 & .089 .168 .770 & 1.696 & $4.99 \%$ \\
\hline $\begin{array}{l}\text { I.10) I can easily use the Turkish equivalents } \\
\text { of ICT terms. }\end{array}$ & .224 & .320 & .090 & .150 & .213 .141 .744 & & \\
\hline
\end{tabular}

Table 3: The convergent and discriminant validity of the measurement model

\begin{tabular}{lcccc}
\hline Factors & $C R$ & AVE & MSV & ASV \\
\hline $\begin{array}{l}\text { Measurement and } \\
\quad \text { Evaluation }\end{array}$ & .87 & .52 & .39 & .20 \\
$\begin{array}{l}\text { Instructional design } \\
\text { Hardware and software }\end{array}$ & .84 & .51 & .31 & .15 \\
$\begin{array}{l}\text { Instructional material } \\
\quad \text { development }\end{array}$ & .83 & .56 & .36 & .19 \\
$\begin{array}{l}\text { Safe and ethical use } \\
\text { Multimedia applications }\end{array}$ & .80 & .51 & .34 & .34 \\
$\quad \begin{array}{l}\text { Use of ICT terms } \\
\text { Mse }\end{array}$ & .89 & .79 & .34 & .39 \\
\hline
\end{tabular}

recommended cut-off point of .5 (Hair et al. 2010). Therefore, the measurement model's both convergent and discriminant validity was evidenced by these computations.

The corrected item-total correlations and other estimates of Cronbach's alpha for the respective factors was calculated ultimately. The corrected item-total correlations ranged from .533 to .792. To put differently, the given results indicate good correlation coefficients for the item discrimination of the scale. Each item's contribution to respective factor revealed that items made a positive contribution to the overall reliability of the scales, since no item was found to detract from the factors. Additionally, another item discrimination analysis was carried out by comparing the total scores of the lower and upper 27 percent groups. Results revealed that the mean difference between upper and lower groups was significant at 1 percent level $(\mathrm{p}<.001)$.

As for test-retest procedure, the scale was administered to sub-sample comprised of $67 \mathrm{stu}-$ dents with two weeks interval. Test-retest reliability was used to confirm the scale's time invariance. Eventually there occurred a relatively strong relationship between test and retest scores. The obtained correlation coefficients ranged from .73 to .92. These results confirm the reliability of the scale in terms of the time invariance.

\section{DISCUSSION}

Once a society recognizes the value of computer use in education also it achieves an awareness of qualitative development of social dynamics (Scott et al. 1992). Perhaps, it is the reason why the integration of technology into educational policy took the lead for a long time (Armfield 2010). In the pursuance of developing a selfefficacy scale for ICT teachers, this study re- 


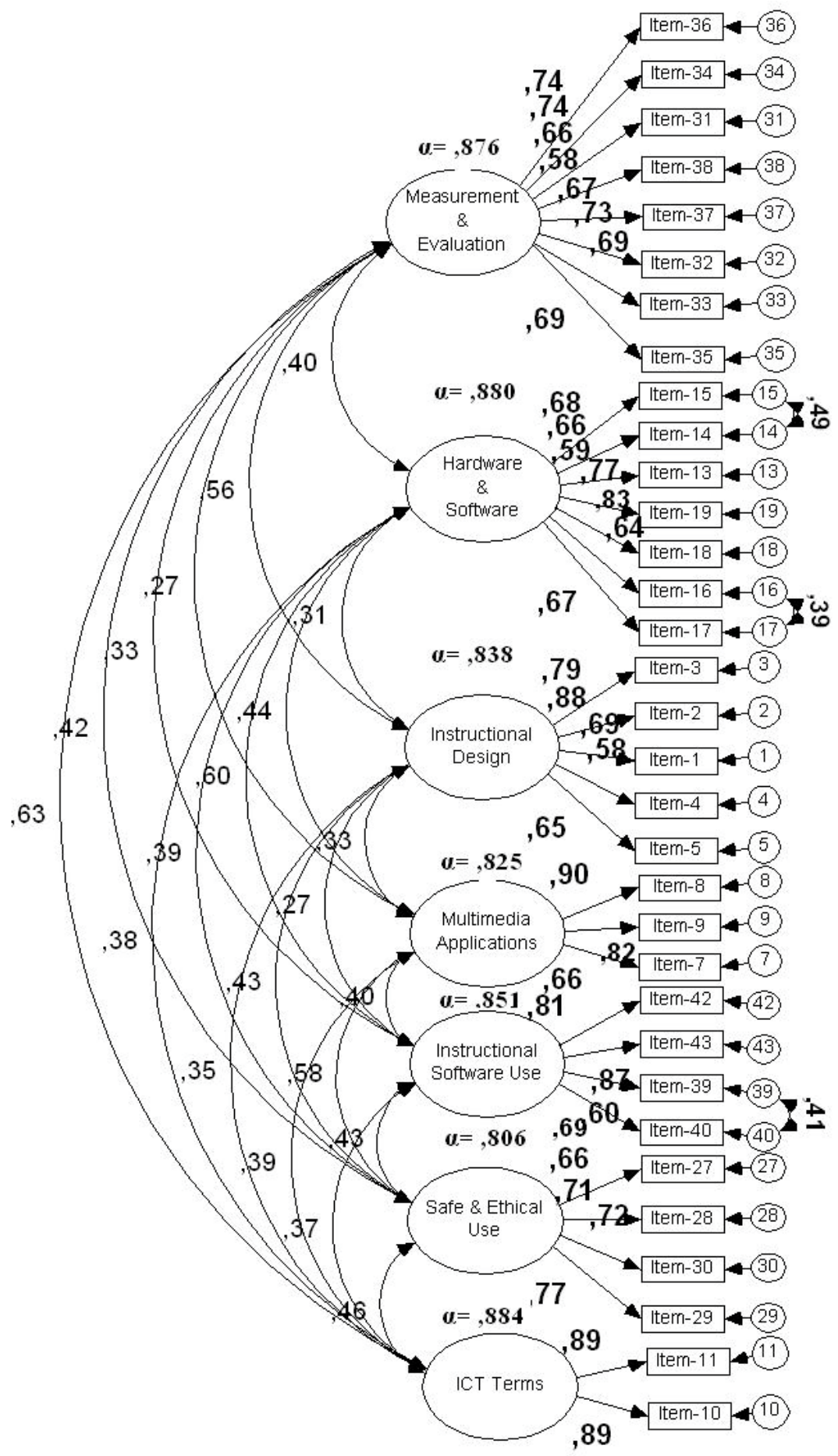

Fig. 1. Confirmatory factor analysis and standardized estimates 
vealed that there are many national and institutional frameworks and standards on the subject of their professional competencies. These national frameworks put forth that it is not enough for teachers to be equipped with ICT skills, but also teachers are able to help students to become collaborative, problem solving and creative learners by means of ICT tools (UNESCO 2011). As Ruben and Van Braak (2012) addressed that development of teachers' ICT skills are not only related to school-based ICT policy plans but also it is a part of national policies on ICT curriculum. Indeed, it is a natural consequence of capacity building need of national human resource so that educational policies embark on updating their present teaching workforce according to up to date content, pedagogy and technology (Danner and Pessu 2013). Also the developed scale covered the concerned three features with seven factors such as content knowledge (use of ICT terms, material development), pedagogical proficiency (instructional design, measurement and evaluation) and technology using ability (hardware and software, multi-media applications, safe and ethical use).

On the other hand, it is possible to further discussion that ICT teachers are not only techsavvy educators for children but also they are main initiators of change dynamics by leading other teachers to use beneficially educational technologies (Lai and Pratt 2004). However, the researchers unfortunately realized that Turkish national framework touched technology leadership role of ICT teacher at all. Indeed, UNESCO (2011) cast a leading role for ICT teachers in providing follow-up support to colleagues and in creating a shared-vision in school by ICT tools. In this sense, Turkish framework rather seemed deficient in leaving technology leadership off the main ICT teacher competencies.

Another point worth to discuss, expert opinions reviewing the draft-scale showed that current national ICT framework of Turkey suffers from some official ideological determinations so the researchers were compelled to omit several items from the draft scale. Ashley (1989) reported that similar ideological references were in exist for apartheid education system of South Africa. Also Connelly et al. (1997) pointed out the holistic nature of teacher knowledge to explain why official ideologies are in search of shaping teachers. Surely thing it is rather tragic to dis- cuss ideological determination on education systems through teacher competencies, still it is a case in point for how some archaic parameters remain standing in the Turkish education system.

\section{CONCLUSION}

The current study aimed to develop a selfreported efficacy scale for ICT teachers, whose items were created according to official Turkish national ICT teacher competency framework spelled out by Turkish Ministry of Education. Based upon the relevant competency framework, seven-factor structure with 34 items was evidenced by EFA and it explained 65.90 percent of the overall variance with .60 of minimum factor loading. At first phase, Harman's single factor analysis was performed to verify the common method bias (CMB) and single-factor unrotated solution accounted for only 30 percent of the overall variance indicating the absence of the CMB issue. The follow-up CFA evidenced the seven-factor construct with acceptable modeldata fit index with one excluded item. As a conclusion, the present research provided a sound psychometric property for the developed scale.

Moreover, the convergent and discriminant validity analyses supported the absence of $\mathrm{CMB}$ through CFA estimates. Besides, the developed measurement model produced robust internal consistency results so that all Cronbach's Alpha coefficients were greater than .80 . Over two week period, test-retest correlations evidenced strong time invariance in reliability. At last factors were named on the basis of their common characteristics such as measurement and evaluation, hardware and software, instructional design, multi-media applications, safe and ethical use, instructional material development, and use of ICT terms.

This study adds to the literature in several respects. First, the developed scale can play an important role in prospective performance management system to be issued by TMONE because the scale items completely based upon official national framework of TMONE. Second, the present research show up a shortcoming of the national framework in combining technology leadership competencies with other competencies because this is the only way to promote ICT teachers being leader for all school share- 
holders in generating a shared vision on technology integrated learning.

\section{RECOMMENDATIONS}

Given the overall psychometric properties of PSS4ICT, the researchers suggest this instrument can be used to assess the professional self-efficacy of ICT teachers. Furthermore, we also believe that PSS4ICT will warrants further studies and development on ICT teachers' self-efficacy perceptions. On the other hand, it is also important to bear in mind some limitations of the current study. When assessing professional competencies, there is an inclination for respondents to underrate or overrate themselves. So the scale scores do not add up to the professional competency but self-efficacy perception about this. This preliminary work on the scale was conducted with pre-service ICT teachers and any further research can be carried out with in-service teachers.

\section{REFERENCES}

Ashley M 1989. Ideologies and Schooling in South Africa. Rondebosch: SATA..

Aesaert K, Vanderlinde R, Tondeur, J, van Braak J 2013. The content of educational technology curricula: A cross-curricular state of the art. Educational Technology Research and Development, 61: 131-151.

Albright JJ, Park HM 2009. Confirmatory Factor Analysis Using Amos, LISREL, Mplus, SAS/STAT CALIS. Indiana University, Indiana/USA: Information Technology Service Publishing.

Armfield SWJ 2010. Planning, designing, implementing and evaluating technology. In: Rosemary Papa (Ed.): Technology Leadership for School Improvement. Thousand Oaks, CA/USA: Sage Publications, pp. 109-128.

Bandura A 1986. Social Foundations of Thought and Action: A Social Cognitive Theory. New Jersey: Prentice-Hall.

Banoglu K 2011. School principals' technology leadership competency and technology coordinatorship. Educational Sciences: Theory and Practice, 11(1): 199-213.

Brinkerhoff J 2006. Effects of a long-duration, professional development academy on technology skills, computer self-efficacy, and technology integration beliefs and practices. Journal of Research on Technology in Education, 39: 24-33.

Compeau DR, Higgins CA 1995. Computer self-efficacy: Development of a measure and initial test. MIS Quarterly, 19: 189-211.

Connelly FM, Clandinin DJ, He MF 1997. Teachers personal practical knowledge on the professional knowledge landscape. Teaching and Teacher Education, 13: 665-674.

Dagiene V 2003. Focus on the Pedagogical Dimension in ICT Literacy for Teachers. In: A McDougall, JS
Murnane, C Stacey, C Dowling, (Eds.): Proc. ICT and the Teacher of the Future - Selected Papers from the International Federation for Information Processing Working Groups 3.1 and 3.3 Working Conference, Melbourne, Australia. CRPIT, 23. ACS. pp. 27-29.

Danner RB, Pessu COA 2013. A survey of ICT competencies among students in teacher preparation programmes athe the University of Benin, Benin City, Nigeria. Journal of Information Technology Education, 12: 33-49.

Devolder A, Vanderlinde R, van Braak J, Tondeur J 2010. Identifying multiple roles of ICT coordinators. Computers and Education, 55: 1651-1655.

Eurydice.org 2004. Key Data on Information and Communication Technology in Schools in Europe. From $<$ http://eacea.ec.europa.eu/education/eurydice/documents/key_data_series/048EN.pdf> (Retrieved November 12,2009 )

Frazier M, Bailey GD 2004. The Technology Coordinator's Handbook. Eugene, OR: International Society for Technology in Education.

Gillaspy JA 1996. A Premier on Confirmatory Factor Analysis. Austin, ED: 395040.

Gorsuch, RL 1983. Factor Analysis. Hillsdale, NJ: Lawrence Erlbaum

Hair JFJ, Anderson RE, Tatham R, Black WC 2010. Multivariate Data Analysis. New Jersey: Prentice Hall.

Hulland J 1999. Use of partial least squares in strategic management research: A review of four recent studies. Strategic Management Journal, 20: 195-204.

International Society for Technology in Education [ISTE] 2008. National Educational Technology Standards for Teachers. $2^{\text {nd }}$ Edition. Washington DC.: ISTE.

Keskinkilic FE 2010. Ilkogretim Bilisim Teknolojileri Oðretmenlerinin Yeterliklerinin Okul Mudurlerinin Goruslerine Gore Degerlendirilmesi [Review of Primary School ICT Teachers' Proficiency in terms of Principals' Views]. Uluslararasi Ogretmen Yetistirme Politikalari ve Sorunlari Sempozyumu Bildiri Kitabi. From <http://www.egitim.hacettepe.edu.tr/belge/ UOYPSS2_BildiriKitabi.pdf> (Retrieved on $25 \mathrm{Au}-$ gust 2010).

Kline RB 2011. Principles and Practice of Structural Equation Modeling. NY: The Guilford Press.

Lai KW, Pratt K 2004. Information and communication technology (ICT) in secondary schools: The role of the computer coordinator. British Journal of Educational Technology, 35(4): 461-475.

Lesisko LJ 2005. The K-12 technology coordinators. The Annual Meeting of the Eastern Educational Research, ED: 490035.

Tavsancil E 2002. Tutumlarin Olculmesi ve SPSS ile Veri Analizi. Ankara: Nobel Yayincilik.

Turkish Ministry of National Education [MEB] 1993. Milli Egitim Bakanligina Bagli Orgun ve Yaygin Egitim Kurumlarinda Bilgisayar Labaratuarlarinin Kurulmasi ve Isletilmesi ile Bilgisayar ve Bilgisayar Koordinator Oðretmenlerinin Gorevleri Hakkindaki Yonerge [Instruction on Building and Running ICT Classrooms in Formal and Informal Education Organizations Connected with Turkish Ministry of National Education and the Tasks of ICT Coordinators] 2378 Sayili Tebliðler Dergisi. Ankara: Author. From <kahta.meb.gov.tr/ 2378_Sayili_Teblig.pdf $>$ (Retrieved on 25 May 2010). 
Ministère de l'Education 2001. Teacher Training : Orientations, Professional Competencies. Québec: Ministère. From <http://www.mels.gouv.qc.ca/dftps/interieur/pdf/formation_ens_a.pdf> (Retrieved on $7 \mathrm{Au}$ gust 2011).

Papa R 2010. Technology leadership standards for the next generation. In: Rosemary Papa (Ed.): Technology Leadership for School Improvement. Thousand Oaks, CA/USA : Sage Publications.

Podsakoff PM, MacKenzie SB, Lee JY, Podsakoff NP 2003. Common method biases in behavioral research: a critical review of the literature and recommended remedies. Journal of Applied Psychology, 88(5): 879903.

Prain V, Hand B 2003. Using new technologies for learning: A case study of a whole school approach. Journal of Research on Technology in Education, 35(4): 441458.

Queensland Departmant of Education 1999. Minimum Standards for Teachers Learning Technology. Queensland/Australia: Queensland Publishing Service.

Ross JA, Hogaboam-Gray A, Hannay L 2001. Effect of teacher efficacy on computer skills and computer cognitions of Canadian students in grades $3-\mathrm{K}$. The Elemantary School Journal, 102(2): 141-156.

Sam HK, Othman AEA, Nordin ZS 2005. Computer self-efficacy, computer anxiety, and attitudes toward the Internet: A study among undergraduates in Unimas. Educational Technology and Society, 8: 205219.

Schumacker RE, Lomax, RG 2004. A Beginner's Guide to Structural Equation Modeling. Lawrance Erlbaum Associates.

Scott T, Cole M, Engel M 1992. Computers and education: A cultural constructivist perspective. Review of Research in Education, 18: 191-251.

Settlage J, Odom AL, Pedersen JE 2004. Uses of Technology by Science Education Professors: Compari- sons With Teachers: Uses and the Current Versus Desired Technology Knowledge Gap. Contemporary Issues in Technology and Teacher Education, 4(3). From $<$ http://www.citejournal.org/vol4/iss3/science/article2. $\mathrm{cfm}>$ (Retrieved on 12 January 2011).

Streiner DL 1994. Figuring out factors: The use and misuse of factor analysis. Canadian Journal of Psychiatry, 39: 135-140.

Strudler NB 1995. The Role of School-Based Technology Coordinators as Change Agents in Elementary School Programs: A Follow-up Study. Paper presented at the Annual Meeting of the American Educational Research Association, New Orleans, LA, 1995. Sumer N 2000. Yapisal esitlik modelleri: Temel kavramlar ve ornek uygulamalar [Structural equation modelling: Basic concepts and sample applications]. Turk Psikoloji Yazilari, 3(6): 74-79.

Teo T, Chai CS, Hung D, Lee CB 2008. Beliefs about teaching and uses of technology among preservice teachers. Asia Pacific Journal of Teacher Education, 36(2): 165-176.

Ullman JB 2001. Structural equation modeling. In: BG Tabachnick, LS Fidell (Eds.): Using Multivariate Statistics. Needhem Heights, MA: Ally and Bacon.

UNESCO 2011. UNESCO ICT Competency Framework for Teachers. Paris: United Nations Educational Press. Worthington RL, Whittaker TA 2006. Scale development research: A content analysis and recommendation for best practices. The Counseling Psychologist, 34(6): 806-838.

Vanderlinde R, Van Braak J, Dexter S 2012. ICT policy planning in a context of curriculum reform: Disentanglements of ICT policy domains and artifacts. Computers and Education, 58: 1139-1350.

Vossler KR 2006. Preparing Teachers as Professional Educators: A New Conception for Pre-service Teacher Education. PhD Thesis, Unpublished. New Zealand: Massey University. 